\title{
A Professionalization Framework in Understanding Migrant labors' Adaptation to China's Industrial Restructuring
}

\author{
Xiuli Yang \\ Department of Economics, Henan University of Science and Technology, Kaiyuan Road, Luoyang, China \\ E-mail:xlyang1012@haust.edu.cn
}

Keywords: migrant labors; professionalization; employment ability; industrial restructuring; economic level

\begin{abstract}
Migrant labors’ professionalization can satisfy the urgent need for China's industrial restructuring, which also helps to fulfill the dream about citizenship of this group in weak position. Through analysis, migrant labors' lack of employment ability accounts for this awkward situation. Migrant labors' professionalization should be long, evolutionary process which can guarantee their stable occupation and sound quality of life, furthermore solve the problem of employment haunting around China's economy.
\end{abstract}

\section{Introduction}

Modern economic development is seen as an identifiable process of growth and change (Solow ,1977), and Syrquin defined it as "an interrelated set of long-run processes of structural transformation that accompany growth”(Syrquin,1988). In an economy labeled as continuous equilibrium, industrial restructuring might appear as the net result of a causative chain of events, beginning with changes in demand and trade which lead to industrialization and result in a steady movement of the labor force from rural to urban occupations (Chenery and Syrquin, 1975).As a consequence, after the transference from rural to urban locations the professionalization of migrant labors must take place with the process of industrial restructuring.

As for the achievement of China's economical development, skilled migration should get certain attention. Apart from the information technology sector, skills migration must involve different economic sectors. Therefore, it's likely that cities will facilitate skilled migratory flows. But the unique household registration system aggravates weak power of labor and gives rise to a host of fundamental labor issues.

In light of the China-style two-sector economy, the first part of this paper addresses itself to the introduction of the issue about migrant labors' professionalization. This reminder of the paper proceeds as follows. In Sect. 2, literature review is provided about the relative study about professionalization. In Sect.3, this paper presents the employment features of the migrant labors. Section 4 and Section 5 examines the professionalization level and the relationship between professionalization level and income respectively. This paper closes with Section 6, namely summary and concluding remarks.

\section{Literature Review}

Professionalization is a broad term which can refer to a variety of education, training and support opportunity available to laborers (Costley, 1998). Related study about professionalization has existed for many decades, but most were often focused on the practitioners from noble and formal vocations, such as lawyers, teachers, doctors, and so on, or some related professions as the object of investigation. Compared with teachers' professionalization, doctor or lawyer's professionalization, migrant laborers' professionalization is really a new term, let alone relational research, which was only mentioned in discussion about farmers' professionalization and laborer barren.

In the study about farmers' professionalization, Wang and Tang suggest the fulfillment of 
farmers' professionalization should be laid on the basis of successful rural surplus labor transfer, (Wang and Tang, 2008). Furthermore, the accomplishment of rural surplus labor's transfer depends crucially on their own employment ability, which is determined by professionalization level to a great degree (Du and Zhang, 2008). Only the completion of professionalization can provide migrant labor with sufficient conditions and further negotiating ability in urban labor market.

Labor barren also arouses scholars' interests in professionalization from different fields. Economics scholars emphasize the influence of labor force transfer (Zhou, 2008), while sociology scholars insist the change of values and the failure in protection of basic rights for this group of people (Liu, 2008). Whatever the emphasis lay, knowledge and skills shortage are necessarily noticed.

In view of China's multidimensional situations, we defined professionalized migrant laborer as a group of people who have succeeded in urbanization transformation, in other words, they have grown into professional workers, which embodies the following characteristics: firstly, these laborers have completely been involved in the process of industrialization who can maximize their interests through the utilization of market mechanism and rules; Secondly, they are different from traditional migrant labors considering mastery of advanced technology and sound employment ability; Thirdly, through assimilation to advanced knowledge and technology under the condition of market economy, they can achieve maximum compensation as well as promotion of industrial modernization.

\section{Employment features of migrant laborers}

With diminishing workforce supply, China can no longer rely on the quantity of workforce to maintain competitive advantages in the global market, but to seek new sources to sustain its long-term growth (Qu and Cai, 2011). How labor shortage in prosperous economy interacts with labor's employment ability has attracted much academic attention, but the existing research rarely involves labor shortage in economic slump and labor's professionalization level.

\subsection{Features of human capital}

As for the human capital of migrant labors, the education level is comparatively low which leads to the popular unskilled laborers. A positive relationship exists between educational level and employee productivity, which indicated that while workforce supply became limited, the improvement of labor productivity and economic growth would be supported by higher labor quality, namely human capital. As Fang Cai pointed out, when workforce becomes a limited and scarce resource, economic development would be accompanied by industrial upgrading, and thus organizations would require employees to obtain higher level of human capital (Cai, 2008 ).

\subsection{Features of employment}

Features of employment are related to an individual and his family's social status, thus a plausible profession is preferred (Goode, 1957). The reality presents an unpleasant situation for migrant laborers. With wide professions distribution of almost every department in China's economy, the low quality labels the migrant laborers labor market. this phenomenon prevailed in labor-intensive, low-skilled professions and areas. Inability in adaptation to urban society, whatever economic level or social level, resulted in a series of problems hindering the process of industrial restructuring. The forth professions for migrant laborers to take on is manufacture, construction industry, wholesale and retailing, and other services.

\subsection{Features of income}

According to economic theory, the price of labor will increase when labor supply becomes no longer abundant. Accompanying upsurge in wage, corresponding improvement in knowledge and skills become necessary. In the meantime, workforce productivity will have to escalate to offset the rise in labor cost and support the competitive advantage through provision of new sources for long-term growth. Therefore, workforce's quality and productivity should be required, which is the 
major concentration of professionalization of migrant laborers. The difference income level indicated that a strong labor productivity growth may partially offset the impact of labor cost increase, and constitute a new competitive source for the Chinese economy. At the same time, China is experiencing an striking economic transformation in structures, traditional industry replace by the third industries.

\section{Professionalization Level of China's Migrant labors}

To qualify migrant labor professionalization level, a first step is to identify the appropriate analytical framework. Referring to methods of conforming index weight adopted both home and abroad, applying Delphi method, this paper establishes the evaluation system for migrant worker's professionalization level by AHP. The concrete indexes are showed in Table 1.

Table 1 Index of migrant labors' professionalization level

\begin{tabular}{|c|c|c|c|c|}
\hline $\begin{array}{l}\text { First-class } \\
\text { indexes }\end{array}$ & $\begin{array}{l}\text { Second-class } \\
\text { indexes }\end{array}$ & $\begin{array}{l}\text { Third-class } \\
\text { indexes }\end{array}$ & $\begin{array}{l}\text { Reference } \\
\text { value for PL }\end{array}$ & $\begin{array}{l}\text { Weight of } \\
\text { third-class } \\
\text { indexes }\end{array}$ \\
\hline \multirow[t]{8}{*}{$\begin{array}{l}\text { Migrant } \\
\text { laborers } \\
\text { PL } \\
\text { indexes }\end{array}$} & \multirow[t]{3}{*}{$\begin{array}{l}\text { Internal } \\
\text { indexes }\end{array}$} & $\begin{array}{l}\text { Percentage of } \\
\text { above high } \\
\text { school graduate } \\
\text { (\%) }\end{array}$ & 80 & 12 \\
\hline & & $\begin{array}{l}\text { Percentage of } \\
\text { skills training } \\
\text { (\%) }\end{array}$ & 90 & 15 \\
\hline & & $\begin{array}{l}\text { Percentage of } \\
\text { middle-aged } \\
\text { population (\%) }\end{array}$ & 75 & 12 \\
\hline & \multirow[t]{5}{*}{$\begin{array}{l}\text { External } \\
\text { indexes }\end{array}$} & $\begin{array}{l}\text { Percentage of } \\
\text { payroll’s timely } \\
\text { delivery (\%) }\end{array}$ & 100 & 15 \\
\hline & & $\begin{array}{l}\text { Labor contract } \\
\text { signing rate (\%) }\end{array}$ & 100 & 13 \\
\hline & & $\begin{array}{l}\text { Weekly rest } \\
\text { time (hour) }\end{array}$ & 124 & 10 \\
\hline & & $\begin{array}{l}\text { Percentage of } \\
\text { wage income } \\
(\%)\end{array}$ & 100 & 14 \\
\hline & & $\begin{array}{l}\text { Percentage of } \\
\text { non-agricultural } \\
\text { population (\%) }\end{array}$ & 70 & 9 \\
\hline
\end{tabular}

Notes: [1] PL refers to professionalization level. 
Table2. Migrant labors’ professionalization level over years 2009-2016

\begin{tabular}{|c|c|c|c|c|c|c|c|c|}
\hline Year & $\begin{array}{l}\text { High } \\
\text { schoo } \\
\text { l } \\
\text { gradu } \\
\text { ate } \\
(\%)\end{array}$ & $\begin{array}{l}\text { Job } \\
\text { trainin } \\
\mathrm{g}(\%)\end{array}$ & $\begin{array}{l}\text { Young and } \\
\text { middle-age } \\
\text { d } \\
\text { population } \\
\text { (\%) }\end{array}$ & $\begin{array}{l}\text { Wage's } \\
\text { timely } \\
\text { payme } \\
\text { nt (\%) }\end{array}$ & $\begin{array}{l}\text { Labor } \\
\text { contra } \\
\text { ct } \\
\text { signin } \\
\text { g rate } \\
(\%)\end{array}$ & $\begin{array}{l}\text { Monthl } \\
\text { y } \\
\text { workin } \\
\text { g time } \\
\text { (Day) }\end{array}$ & $\begin{array}{l}\text { Incom } \\
\text { e } \\
\text { per } \\
\text { month } \\
\text { (Yuan) }\end{array}$ & $\begin{array}{l}\text { Numbe } \\
\mathrm{r} \\
\text { (millio } \\
\mathrm{n} \\
\text { persons } \\
\text { ) }\end{array}$ \\
\hline 2009 & 24.3 & 48.9 & 83.9 & 98.2 & 42.8 & 26 & 1417 & 229.78 \\
\hline 2010 & 25.2 & 47.6 & 65.9 & 98.6 & 42.0 & 26.2 & 1690 & 242.23 \\
\hline 2011 & 23.0 & 36.7 & 61.7 & 99.2 & 43.8 & 25.4 & 2049 & 252.78 \\
\hline 2012 & 23.7 & 32.7 & 59.3 & 99.5 & 43.9 & 25.3 & 2290 & 262.61 \\
\hline 2013 & 23.7 & 32.7 & 58.4 & 99.2 & 38 & 25.2 & 2609 & 268.94 \\
\hline 2014 & 23.8 & 34.8 & 56.4 & 99.4 & 38 & 25.3 & 2864 & 273.95 \\
\hline 2015 & 22.8 & 32.7 & 65.9 & 99.2 & 36.2 & 25.2 & 3072 & 277.47 \\
\hline 2016 & 23.8 & 34.8 & 56.5 & 99.2 & 35.1 & 24.9 & 3275 & 281.71 \\
\hline
\end{tabular}

Notes: Table 2 is constructed based on NBSC: China Labor Statistical Yearbook (2009-2016), Statistical Yearbook of China (2009-2016)

The above figure shows that in the past decade China migrant labors' professionalization level demonstrates an upward tendency as a whole, however, a few fluctuations occurred due to the 2003 SARS and the follow-up ramification of 2008 international financial crisis. China migrant labors' professionalization level poised a low level by and large, and a long stretch is facing this special group.

\section{Professionalization level and net income of migrant laborers}

Assumption: A positive relationship exists between professionalization level and net income of migrant laborers.

To examine the nature of observational data on the two variables in scatter plot, we applied the OLS of the Eviews software package to derive their inherent relationship, which in turn leads to the following econometric specifications:

$\operatorname{LnY}_{\mathrm{i}}=\mathrm{a}_{0}+\mathrm{b}_{1} \mathrm{X}_{\mathrm{i}}(1)$

where $\mathrm{Y}$ si the net income of migrant laborers, $\mathrm{X}$ is the professionalization level, $\mathrm{a}_{0}, \mathrm{~b}_{1}$ are parameters to be estimated. Based on the time series data from the year 2002 to 2011, we estimated the models using ordinary least squares, with results listed in equating (2).

$$
\begin{aligned}
& \operatorname{LnY}=5.197+0.042 X \quad(2) \\
& \mathrm{t}=(5.75) \\
& \mathrm{R}^{2}=0.80 \quad \mathrm{~F}=33.01 \quad \mathrm{DW}=1.84
\end{aligned}
$$

As can be seen in equation (2), the estimating of Equation (1) achieved a fairly acceptable $\mathrm{R}^{2}$ measures of model fit, and a further standard regression diagnostics also reveals no problem on the tests of model specification robustness (F statistic) and residual heteroskedasticity (DW). As suggested in the above equation, the variable of professionalization level bears out a positive relationship with the dependent variable of net income with a correlation coefficient (0.042).

\section{Conclusion}

In this paper, we have provided updates on the stylized facts regarding the professionalization level of migrant labors. Our empirical strategy was based on the econometric specification and estimation by using a time series data set. While our results corroborate previous findings on the migrant labors' lack of employment skills, we are able to provide new insights as to the paradox of migrant labor shortage and rural labor supply abundance.

The role of professionalization level increase in the accompanying industrial restructuring is 
inherent intellectual interest. Even in an applied sense, a timely updated understanding of the true ability in professionalization and industrial restructuring is extremely vital to enable China to follow proper paths in the economic development and industrial restructuring process.

\section{Acknowledgements}

Project information: The education department of Henan Province social science project: Project name: Research on Peasants' participation mechanism and path towards supply of rural public goods under the guidance of supply side reform in Henan Province. Project number: Project number:2017-ZZJH-143

\section{References}

[1] Cai, F.2008. Lewis Turning Point: A Coming New Stage of China's Economic Development, Social Science Academic Press, Beijing.

[2] Chenery HB, Syrquin M.1975. Patterns of development, 1950-1970. Oxford University Press, Oxford.

[3] Costley, J. 1998. Building a professional development system that works for the field of out-of-school-time. Wellesley, MA: National Institute on Out-of-school Time.

[4] Du X, Zhang G. 2008. Occupation education--another choice for accelerate the transformation of rural labor. Economic Research Guide, 33:47-50.

[5] Goode, W.J. 1957. Community within a community: The Professions. American Sociological Review, 22: 194-200.

Liu Z. 2008. An empirical study of migrant labor shortage. China Opening Herald, 4:84-90.

[6]Lu 2010.2 The misunderstood labor barren. http://lumingfudan.blog.sohu.com/159889529.html. Solow RM .1977. Comment to H.B.Chenery "Transitional growth and world industrialization. In: Ohlin B et al (eds) The international alloc

[7] Syrquin M.1988. Patterns of structural change. In: Chenery HB, Srinivasan TN(eds) Handbook of development economics, North-Holland, Amsterdam, 2: 197-273.

[8] Wang Y, Tang J. 2008. Analysis on obstructions and countermeasures of farmers professional employment. Journal of Hebei Agricultural Sciences, 9:129-131.

[9] Yue Qu and Fang Cai. 2011. Understanding China's workforce competitiveness: a macro analysis . Journal of Chinese Human Resource Management, 2 :8-22.

[10]Zhou J. 2008. Discussion and application of labor force transfer model, on migrant labor shortage. Lanzhou Academic Journal, 72: 88-91. 